\title{
Storage and sensory characteristics according to drying methods of dried oriental melon
}

\author{
Hansol Koo ${ }^{1}$, Jieon Lee ${ }^{1}$, Hyuna Jung ${ }^{2 *}$ \\ ${ }^{1}$ Department of Herbal Food Science Graduate School, Daegu Hanny University, Gyeongsan 38610, Korea \\ ${ }^{2}$ Department of Herbal Cuisine and Nutrition, Daegu Hanny University, Gyeongsan 38610, Korea
}

\section{건조 참외의 건조방법에 따른 저장 및 관능특성}

\author{
구한솔 ${ }^{1}$ - 이지언 ${ }^{1}$ - 정현아 ${ }^{2 *}$ \\ ${ }^{1}$ 대구한의대학교 대학원 한방식품학과. ${ }^{2}$ 대구한의대학교 한방식품조리영양학부
}

\begin{abstract}
This study aims to develop processing and storage conditions for improving the ease of consumption of oriental melon by investigating the changes in its quality and sensory characteristics as a function of the storage period and drying method. Various drying methods were investigated, and the moisture content of the cold air-dried oriental melon was stable from the fifth day. The $\mathrm{pH}$ varied significantly during storage (about $\mathrm{pH} 5-6, \mathrm{p}<0.01,0.001$ ), and the sugar content increased significantly in all treatment groups. The chromaticity, which is indicated by the $L$ value, was highest in freeze-drying, and did not vary significantly after cold air- and freeze-drying, and remained the same during storage. The storage period for freeze-drying was loger $(p<0.001)$, and the various physical properties, such as strength, hardness, chewiness, and brittleness, did not show significant variation from the fifth day of storage. Significant difference in springiness was not observed, and this characteristic was maintained during storage. The total bacterial count was lowest with a value of $4.02 \mathrm{log} \mathrm{CFU} / \mathrm{g}$ on the first day of the freeze-drying storage but increased upon longer storage. However, significant changes in this parameter in comparison to other treatment groups were not observed. The results indicated that the preferred method of achieving the best sensory characteristics, which included superior aroma and chewiness, was cold air-drying. To prevent changes to the quality characteristics of dried oriental melon, follow-up conditions and procedures, such as the use of hygienic drying environment, storage at $4^{\circ} \mathrm{C}$, and vacuum packaging and sterilized packing paper are necessary. The data disclosed in this study will form the basis for further development of conditions for efficient processing of oriental melon and health food using the cold air-drying method for preserving the quality and delivering optimal storage conditions.
\end{abstract}

Key words : oriental melon, hot air-drying, cold air-drying, freeze-drying, quality characteristics

\section{서 론}

참외(Cusumis melon L.)는 cucurbitaceae에 속하는 단년생 식물로 멜론류의 변종이며, 중앙아시아의 고온건조한 지역 에서 서식한다(1). 참외는 전 세계적으로 oriental melon,

*Corresponding author. E-mail : jungha@dhu.ac.kr

Phone : 82-53-819-1593, Fax : 82-53-819-1494

Received 05 November 2018; Revised 08 April 2019; Accepted 03 September 2019.

Copyright (c) The Korean Society of Food Preservation. All rights reserved. cantaloupe, honeydew melon 및 muskmelon 등 매우 다양한 종류로 구분된다(2). 참외는 여름에 재배되는 과채류로 수 분함량과 당도가 높고 칼슘, Vit. $\mathrm{A}, \mathrm{C}$ 가 풍부하며 참외의 포도당과 과당은 흡수가 빨라 피로 회복에 도움을 준다 $(1,3)$. 또 항암효과가 뛰어난 cucurbitacin이라는 성분을 함 유하고 있어 독특한 향기와 시원한 맛 때문에 여름철 과실 로 인기가 많다(4). 그러나 참외는 저온에서 장기간 저장성 이 불량하고 유통과정이 어렵고(5), 과잉생산 및 기형, 이상 과(果)의 발생으로 경제적 손실이 매우 크게 발생되고 있어 (6), 다양한 가공방법이 요구되고 있다. 우리나라에서는 수 확참외 대부분이 생과로 소비되고 있으며 일부가 장아찌, 
김치 등 절임반찬 등으로 이용되고 있다(3). 참외관련 선행 연구로는 전처리 방법을 달리한 건조참외(2), 유산균을 이 용한 참외 발효식품(7), 참외 농축액을 첨가한 무증자 쌀막 걸리(1), 참외 와인(8), 참외 잼(9) 등 상품 가치가 떨어지는 참외를 이용하여 경제적 손실을 줄일 수 있는 가공방법의 연구가 보고되고 있으나, 참외 보관 및 유통, 간편식 형태의 제품 등 다양한 가공식품(10)의 응용 연구가 미흡하기 때문 에 저장과 섭취가 용이한 가공제품의 연구가 시급하다.

식품 건조는 수분함량이 높은 식품의 수분을 제거하는 가공 처리 방법으로 식품 산업에서 많이 이용되고 있으며 미생물에 의한 변질이나 부패를 방지하고 수송성과 저장성 을 향상시키는(11) 등 수분이 다량 함유 된 과일, 채소류에 매우 중요한 가공방법이다(12). 건조 방법으로는 천일건조 와 인공 건조법으로 구분되며 인공 건조법으로는 냉풍건 조, 열풍건조가 있고 산업의 발전으로 인해 동결건조, 원적 외선, 마이크로파 방법 등이 이용되고 있다(13). 최근 건조 가공 제품으로는 해외 농산물을 이용한 건망고, 건파인애 플, 건조바나나 스낵 등이 있으며 국내 농산물을 이용한 건자두, 건배, 건사과, 건딸기 등 당, 첨가물 처리가 되었거 나 원료 그대로 건조한 다양한 제품이 생산되고 있다(14). 인공 건조법은 해충이나 미생물에 의해 오염될 확률이 낮아 위생적으로 건조되며 색이나 일반성분 손실이 적다고 하였 다 $(15,16)$. 인공 건조법 중 열풍건조는 건조시간이 빠르고 경제적이나 열로 인해 식품의 영양가 저하와 맛, 텍스쳐, 색상 등의 문제점이 발생된다고 보고되었다(17). 냉풍건조 는 식품의 향과 색, 맛을 그대로 유지할 수 있지만 건조 시간이 길다는 단점이 있다(18). 동결건조는 수분의 액상이 변동 되지 않은 상태에서 직접 얼음을 승화시켜 건조 한 제품을 얻는 방법으로식품의 텍스쳐, 향, 색, 영양성분의 변화가 적으나 건조 비용이 높은 단점이 있다(19-21).

본 연구는 산업적으로 많이 사용되고 있는 건조 방법을 사용하여 참외를 각각 열풍건조, 냉풍건조, 동결건조한 후 저장기간에 따른 품질특성 변화를 비교 평가하여 가장 적합 한 건조방법을 찾고자 하였다. 또한, 보관 및 유통, 간편식 형태의 제품으로 개발하여 참외의 향후 소비촉진에 기여하 고자 한다.

\section{재료 및 방법}

\section{실험 재료}

본 실험에 사용한 참외는 2017년 7월 경북 칠곡군 북삼친 환경참외연구회에서 재배한 평균 $340 \mathrm{~g}$ 의 벌꿀참외를 구입 하여 사용하였다.

\section{건조 참외의 제조 방법}

건조 참외의 제조는 참외를 흐르는 물에 씻어 이물질을
제거한 후, 껍질을 박피하였다. 이후 직경으로 반을 잘라 속을 제거한 후 슬라이스 기기(Premium Electric Slicer, mode 610, Chef's Choice, U.S, USA)를 이용하여 $2 \mathrm{~cm}$ 로 잘랐다. 참외는 졸깃한 식감으로 맞추기 위해 2 시간마다 열풍, 냉풍, 동결건조하면서 예비 실험으로 기호도가 가장 높은 수분함량 조건을 탐색하였다. 최종수분함량은 열풍건 조 $6.57 \%$, 냉풍건조 $9.30 \%$, 동결건조 $7.58 \%$ 내외로 설정하 였다. 최적 조건으로 열풍건조는 열풍건조기(LD-918BH, L'EQUIP, Hwaseong, Korea)로 $50^{\circ} \mathrm{C}$ 에서 30시간 건조하였 다. 냉풍건조는 냉풍건조기(JJ-1000, Junjin e\&c, Gyeongsan, Korea)로 $30^{\circ} \mathrm{C}$ 에서 57시간 건조하였다. 동결건 조는 $-80^{\circ} \mathrm{C}$ 급속냉동고(MDF-U52V, SANYO, Tokyo, Japan)에서 24시간 급속 냉동 후, 진공동결건조기(FD-8512, ILSHIN, Namyangju, Korea)에서 43시간 동결건조 하였다. 건조한 참외의 저장은 참외를 포장지(polyethylene +polyamide, 내열 $100^{\circ} \mathrm{C}$, 내냉 $-20^{\circ} \mathrm{C}$ )에 밀봉하여 드라이오 븐기(VS-120203, VISION SCIENTIFIC, Daejeon, Korea) $20^{\circ} \mathrm{C}$ 에서 보관하였다. 저장기간은 예비실험 결과, 15 일차 이후 품질 변화가 크게 나타나므로 선행연구, Yoo (22)의 건조식품의 보관온도 연구에 기하여 동일하게 건조가 끝났 을 때를 저장 1 일차로 하였고, 저장 5 일차, 저장 10 일차, 저장 15 일차에 저장이 이루어졌다.

\section{수분 측정}

건조한 참외의 수분 측정은 시료 $3 \mathrm{~g}$ 을 정밀형 적외선 수분측정기(MB120, Ohaus, Cangzhou, China)를 이용하여 3 회 반복 측정하여 평균값표준편차로 나타내었다.

\section{$\mathrm{pH}$ 측정}

건조한 참외의 $\mathrm{pH}$ 는 시료 $10 \mathrm{~g}$ 과 증류수 $90 \mathrm{~mL}$ 를 호모게 나이저 컵에 넣고 Homogenizer(AM-7, NIHONSEIKI KAISHA, Tokyo, Japan)를 이용하여 균질화 하였다. 균질화 된 참외는 여과지(Whatman No.4)를 이용하여 $100 \mathrm{~mL}$ 메스 플라스크에 여과한 후 정용한 시료 용액으로 $\mathrm{pH}$ meter (Delta 320, Mettler-Toledo, Cangzhou, China)를 이용하여 3회 반복 측정하여 평균값 \pm 표준편차로 나타내었다.

\section{당도 측정}

건조한 참외의 당도는 시료 $10 \mathrm{~g}$ 과 증류수 $90 \mathrm{~mL}$ 를 호모 게나이저 컵에 넣고 Homogenizer(AM-7, NIHONSEIKI KAISHA, Tokyo, Japan)를 이용하여 균질화 하였다. 균질화 된 건조 참외는 여과지(Whatman No.4)를 이용하여 $100 \mathrm{~mL}$ 메스플라스크에 여과한 후 정용한 시료 용액으로 굴절당도 계(poket PAL-Patissier, ATAGO, Tokyo, Japan)로 3회 반복 측정하여 환산 후 가용성 고형분 함량(ㅁix)으로 표시하였 고, 평균값 \pm 표준편차로 나타내었다. 


\section{색도 측정}

건조한 참외의 색도는 색차계(DP-400, MINOLTA, Osaka, Japan)를 이용하여 명도(L, lightness), 적색도(a, redness), 황색도(b, yellowness) 값을 3회 반복 측정하여 평 균값 \pm 표준편차로 나타내었다. 이때 사용한 표준 백색판 (standard plate)의 $\mathrm{L}$ 값은 $84.21, \mathrm{a}$ 값은 $0.32, \mathrm{~b}$ 값은 0.32 이었 다.

\section{물성 측정}

건조한 참외의 물성은 Sun rheo meter(COPAC-100П, Sun Scientific, Tokyo, Japan)를 사용하여 측정하였다. 측정 조건에서 test type은 mode21, distance $15 \mathrm{~mm}$ plunger diameter $300 \%$, adaptor type No. 4, table speed $60 \mathrm{~mm} / \mathrm{m}$, $\operatorname{load} \operatorname{cell}(\max ) 2 \mathrm{~kg}$ 의 조건으로 시료 중심부에 2회 연속 측정하였을 때 얻어지는 값을 산출하였고, 강도(strongness), 경도(hardness), 응집성(cohesiveness), 탄력성(springiness), 씹음성(chewiness), 깨짐성(brittleness)을 3회 반복 측정하 여 평균값 \pm 표준편차로 나타내었다.

\section{총 균수 검사}

건조한 참외의 총 균수 검사는 시료 $10 \mathrm{~g}$ 을 취한 뒤 멸균 수 $90 \mathrm{~mL}$ 를 호모게나이저 컵에 넣고 Homogenizer(AM-7, NIHONSEIKI KAISHA, Tokyo, Japan)를 이용하여 균질화 시킨 후 시료액을 $1 \mathrm{~mL}$ 취하여 $9 \mathrm{~mL}$ 의 멸균수로 10 배 단계희석 하였다. 각 단계 희석액 $1 \mathrm{~mL}$ 를 $3 \mathrm{M}$ petrifilm (Petrifilm $^{\mathrm{TM}}$ plate, $3 \mathrm{M}$ Co., St. Paul, MN, USA)에 접종하여 $37 \pm 1^{\circ} \mathrm{C}$ 배양기(HB-101M, HANBAEK ST, Bucheon, Korea) 에서 24시간 배양시킨 후 $\log \mathrm{CFU} / \mathrm{g}$ 로 표시하였다.

\section{관능 평가}

건조한 참외 관능검사의 모든 시료는 관능 패널 요원의 섭취 안전성을 고려하여 저장 1 일차에 대한 시료만 사용하 였다. 패널 요원은 대구한의대학교 한방식품조리영양학부
에 재학 중인 학부생 20 명을 선정하여 실험 전 실험의 목적 과 관능평가에 대한 충분한 지식, 용어, 평가기준 등을 숙지 시킨 후 평가에 응하도록 하였다. 시료번호는 난수표를 이 용하여 5자리 숫자로 표시하였으며 모든 시료는 동시에 제공하였다. 평가 항목은 기호도와 강도로 평가되었다. 기 호도는 관능 시료에 대한 기호를 평가하며, 강도는 관능 시료에 대한 강한정도를 평가하는 것으로 기호도는 외관 (appearance), 색(color), 향(flavor), 이취(off-flavor), 맛 (taste), 단맛(sweetness), 쓴맛(bitterness), 질감(texture), 탄력 성(springness), 씹음성(chewsiness), 전체적인 기호도 (overall palatability) 11 가지 항목을 평가하였다. 강도는 기 호도 평가 11 개 항목 중 외관(appearance)과 전체적인 기호 도(overall palatability)를 제외한 9가지 항목으로 평가하였 다. 평가 점수가 7에 가까울수록 높은 기호도와 강도를 나타 내는 7점 척도법으로 관능 특성을 평가하도록 하였다. 관능 검사를 진행하기 전 대구한의대학교 부속 대구한방병원 임상시험심사위원회에서 승인(승인번호: DHUMC-D17025-PRO-01)을 얻어 안전하게 실시하였다.

\section{통계분석}

실험결과에 대한 모든 결과는 SPSS Program(ver.23.0, SPSS Inc, Chicago, IL, USA)을 이용하여 평균표준편차를 산출하였고, 차이비교를 위해 분산분석(one-way ANOVA) 을 실행하였다. 분산분석 차이비교 결과, 유의적인 차이가 있을 경우, $\mathrm{p}<0.05$ 수준에서 Duncan's multiple range test를 실시하여 시료간의 유의성을 검증하였다.

\section{결과 및 고찰}

\section{수분 변화}

건조 참외의 저장기간 중 수분 변화에 대한 결과는 Table 1 과 같다. 건조를 거치지 않은 생 참외의 수분함량은

Table 1. Changes in the moisture content $(\%)$ of oriental melon according to drying method

\begin{tabular}{|c|c|c|c|c|c|}
\hline \multirow{2}{*}{ Sample } & \multicolumn{4}{|c|}{ Storage period (day) } & \multirow{2}{*}{ F-value } \\
\hline & 1 & 5 & 10 & 15 & \\
\hline $\mathrm{HAD}^{1)}$ & $4) \mathrm{b} 6.57 \pm 0.12^{\mathrm{A} 5)}$ & ${ }^{\mathrm{b}} 6.49 \pm 0.17^{\mathrm{A}}$ & $5.27 \pm 0.06^{\mathrm{B}}$ & ${ }^{c} 5.38 \pm 0.13^{B}$ & $99.86^{* * *}$ \\
\hline$C A D^{2)}$ & ${ }^{\mathrm{a}} 9.30 \pm 0.98^{\mathrm{A}}$ & ${ }^{\mathrm{a}} 7.45 \pm 0.01^{\mathrm{B}}$ & ${ }^{b} 7.27 \pm 0.02^{B}$ & ${ }^{\mathrm{a}} 7.67 \pm 0.15^{\mathrm{B}}$ & $10.71^{* *}$ \\
\hline $\mathrm{FD}^{3)}$ & ${ }^{\mathrm{b}} 7.58 \pm 0.15^{\mathrm{A}}$ & ${ }^{\mathrm{a}} 7.48 \pm 0.08^{\mathrm{A}}$ & ${ }^{\mathrm{a}} 7.46 \pm 0.11^{\mathrm{A}}$ & ${ }^{\mathrm{b}} 6.30 \pm 0.02^{\mathrm{B}}$ & $110.376^{* * *}$ \\
\hline F-value & $17.37^{* \star 6)}$ & $79.41^{* * *}$ & $828.26^{* * *}$ & $297.67^{* * \star}$ & \\
\hline
\end{tabular}

Mean \pm SD.

${ }^{1)} \mathrm{HAD}$ : Hot air-drying.

${ }^{2)} \mathrm{CAD}$ : Cold air-drying.

${ }^{3)} \mathrm{FD}$ : Freeze-drying.

4)a-d Means with different superscript in the same column are significantly different $(p<0.05)$ by Duncan's multiple range test.

${ }^{5) A-D}$ Means with different superscript in the same row are significantly different $(p<0.05)$ by Duncan's multiple range test.

${ }^{* *} \mathrm{p}<0.01, \quad{ }^{* * *} \mathrm{p}<0.001$ 
$89.09 \%$ 였다. 저장 1 일차의 건조 참외는 열풍건조가 $6.57 \%$, 냉풍건조 $9.30 \%$, 동결건조 $7.58 \%$ 로 생 참외에 비해 건조 참외는 수분이 $80 \%$ 정도로 감소하였다. 건조방법을 달리한 참외의 저장기간 중 수분은 저장기간이 길어질수록 모든 처리군에서 유의적으로 감소하는 경향을 나타냈다 $(\mathrm{p}<0.01$, $\mathrm{p}<0.001)$. 냉풍건조의 경우 저장 5 일차부터 변화 없이 유지 되었으며 유의적인 변화 또한 없었다. 동결건조는 저장기 간 동안 유지하는 경향을 보이다가 저장 15 일차에 변화되 었다. 건조참외 저장 시 수분의 변화를 방지하기 위해 산소 의 접촉을 최소로 하여 진공포장, 탈 흡수제 첨가 또는 저온 저장 등 보관 방법의 추가 연구가 진행 되어야 한다고 사료 된다.

\section{$\mathrm{pH}$ 변화}

건조 참외의 저장 기간 중 $\mathrm{pH}$ 변화에 대한 결과는 Table 2 와 같다. 건조를 거치지 않은 생 참외의 $\mathrm{pH}$ 는 5.20 으로 약산성을 띄고 있었으며 건조참외의 저장 1 일차 $\mathrm{pH}$ 는 냉풍 건조, 동결건조, 열풍건조 순으로 높게 나타났고 $(\mathrm{p}<0.05)$, $\mathrm{pH}$ 5.96-5.98 정도로 생 참외에 비해 높게 나타났다. Lee와
$\operatorname{Kim}(12)$ 의 건조방법에 따른 아로니아 연구에서는 $\mathrm{pH}$ 3.90-3.92 정도로 생과 보다 높게 나타났으며, 유의적인 차 이는 없었으므로 건조에 따른 영향이 크지 않다고 하였다. 본 연구의 건조방법을 달리한 참외 $\mathrm{pH}$ 는 유의적인 차이를 나타내었지만 건조 아로니아 연구(12)의 $\mathrm{pH}$ 와 0.02 차이의 유사한 범위의 차이를 나타낸 것으로 보아 선행연구의 결과 와 유사하게 나타났다. 건조방법을 달리한 참외의 저장기 간 중 $\mathrm{pH}$ 변화는 $\mathrm{pH}$ 5.63-6.08 범위 내에서 유의적인 변화를 나타냈다 $(\mathrm{p}<0.001)$.

\section{당도 변화}

건조 참외의 저장기간 중 당도 변화에 대한 결과는 Table 3 과 같다. 건조를 거치지 않은 생 참외의 당도는 2.08 ${ }^{\circ} \mathrm{Brix} / 10 \mathrm{~g}$ 이였으며, 건조참외의 저장 1 일차 당도는 4.67-5.27 ${ }^{\circ} \mathrm{Brix} / 10 \mathrm{~g}$ 정도로 동결건조, 열풍건조, 냉풍건조 순으로 높게 나타났다. Lee와 $\operatorname{Kim}(12)$ 의 건조방법에 따른 아로니아의 품질특성 연구에서 건조한 아로니아의 당도가 동결건조, 열풍건조, 냉풍건조의 순으로 높은 함량으로 나 타났으므로 본 연구와 동일한 결과를 보였다. 건조방법을

Table 2. Changes in the $\mathrm{pH}$ of oriental melon according to drying method

\begin{tabular}{|c|c|c|c|c|c|}
\hline \multirow{2}{*}{ Sample } & \multicolumn{4}{|c|}{ Storage period (day) } & \multirow{2}{*}{ F-value } \\
\hline & 1 & 5 & 10 & 15 & \\
\hline $\mathrm{HAD}^{1)}$ & 4)b $5.96 \pm 0.01^{\mathrm{B} 5)}$ & ${ }^{\mathrm{a}} 6.08 \pm 0.03^{\mathrm{A}}$ & ${ }^{\mathrm{a}} 5.89 \pm 0.01^{\mathrm{C}}$ & ${ }^{\mathrm{c}} 5.77 \pm 0.02^{\mathrm{D}}$ & $123.12^{* \star \star}$ \\
\hline $\mathrm{CAD}^{2)}$ & ${ }^{\mathrm{a}} 5.98 \pm 0.01^{\mathrm{A}}$ & ${ }^{b} 5.90 \pm 0.01^{B}$ & ${ }^{b} 5.85 \pm 0.01^{C}$ & ${ }^{\mathrm{a}} 5.86 \pm 0.00^{\mathrm{C}}$ & $170.29^{* * *}$ \\
\hline $\mathrm{FD}^{3)}$ & ${ }^{\mathrm{a}} \mathrm{b} 5.97 \pm 0.01^{\mathrm{A}}$ & ${ }^{\mathrm{c}} 5.84 \pm 0.03^{\mathrm{C}}$ & ${ }^{\mathrm{a}} 5.89 \pm 0.02^{\mathrm{B}}$ & ${ }^{b} 5.63 \pm 0.01^{D}$ & $198.20^{* * *}$ \\
\hline F-value & $9.00^{* 6)}$ & $63.82^{* * *}$ & $12.08^{* *}$ & $302.25^{* * \star}$ & \\
\hline
\end{tabular}

Mean \pm SD.

${ }^{1)} \mathrm{HAD}$ : Hot air-drying.

${ }^{2)} \mathrm{CAD}$ : Cold air-drying.

${ }^{3)} \mathrm{FD}$ : Freeze-drying.

${ }^{4) a-d}$ Means with different superscript in the same column are significantly different $(p<0.05)$ by Duncan's multiple range test.

${ }^{5) A-D}$ Means with different superscript in the same row are significantly different $(p<0.05)$ by Duncan's multiple range test.

6) $\mathrm{p}<0.05, \quad{ }^{* *} \mathrm{p}<0.01,{ }^{* * *} \mathrm{p}<0.001$

Table 3. Changes in the sugar contents $(\%)$ oriental melon according to drying method

\begin{tabular}{|c|c|c|c|c|c|}
\hline \multirow{2}{*}{ Sample } & \multicolumn{4}{|c|}{ Storage period (day) } & \multirow{2}{*}{ F-value } \\
\hline & 1 & 5 & 10 & 15 & \\
\hline $\mathrm{HAD}^{1)}$ & 4)ns $4.80 \pm 0.00^{(5)}$ & ${ }^{\mathrm{a}} 6.13 \pm 0.12^{\mathrm{B}}$ & ${ }^{b} 6.33 \pm 0.23^{B}$ & ${ }^{\mathrm{a}} 7.47 \pm 0.12^{\mathrm{A}}$ & $179.28^{* * x}$ \\
\hline $\mathrm{CAD}^{2)}$ & ${ }^{\mathrm{ns}} 4.67 \pm 0.31^{\mathrm{C}}$ & $\mathrm{b}_{5} .80 \pm 0.20^{\mathrm{B}}$ & ${ }^{b} 6.47 \pm 0.12^{\mathrm{A}}$ & ${ }^{\mathrm{c}} 6.53 \pm 0.12^{\mathrm{A}}$ & $56.22^{* * *}$ \\
\hline $\mathrm{FD}^{3)}$ & ${ }^{\mathrm{ns}} 5.27 \pm 0.50^{\mathrm{C}}$ & ${ }^{\mathrm{a}} 6.27 \pm 0.12^{\mathrm{B}}$ & ${ }^{\mathrm{a}} 7.13 \pm 0.12^{\mathrm{A}}$ & ${ }^{b} 6.93 \pm 0.12^{A}$ & $28.97^{* * *}$ \\
\hline F-value & $\mathrm{ns}^{6}$ & $7.80^{* 77}$ & $20.67^{* *}$ & $49.33^{* * *}$ & \\
\hline
\end{tabular}

Mean \pm SD.

${ }^{1)} \mathrm{HAD}$ : Hot air-drying

${ }^{2)} \mathrm{CAD}$ : Cold air-drying.

${ }^{3)} \mathrm{FD}$ : Freeze-drying.

${ }^{4) a-d}$ Means with different superscript in the same column are significantly different $(\mathrm{p}<0.05)$ by Duncan's multiple range test

${ }^{5) A-D}$ Means with different superscript in the same row are significantly different $(\mathrm{p}<0.05)$ by Duncan's multiple range test.

${ }^{6}$ ns : none significant.

$7)^{*} \mathrm{p}<0.05, \quad{ }^{* *} \mathrm{p}<0.01,{ }^{* * *} \mathrm{p}<0.001$ 
달리한 참외의 저장기간 중 당도는 저장기간이 길어질수록 유의적으로 증가하였다(p<0.001). Kim 등(23), Lee 등(24) 의 건조방법을 달리한 감말랭이, 오미자의 연구에 의하면 수분함량이 높을수록 가용성 고형분 함량이 낮고, 수분함 량이 낮을수록 가용성 고형분 함량이 높아진 것으로 보아 이들 간의 연관성을 확인할 수 있으며 본 연구와 유사하였 다.

\section{색도 변화}

건조 참외의 저장기간 중 색도 변화에 대한 결과는 Table 4과 같다. 저장기간 별 건조방법에 따른 $\mathrm{L}$ 값의 차이는 저장 1 일차에서 동결건조, 냉풍건조, 열풍건조 순으로 높게 나타 났다 $(\mathrm{p}<0.001) . \mathrm{b}$ 값의 차이는 저장 1 일차에서 열풍건조, 냉 풍건조, 동결건조 순으로 높게 나타났다. Kwon 등(25)의 건조 마 연구에서는 L값이 동결건조가 가장 높게 나타났고 열풍건조가 가장 낮게 나타났으며, Park 등(26)의 연구에서 는 열풍건조 블루베리의 $\mathrm{b}$ 값이 높게 나타났다. 선행연구 (26)에서는 동결건조에 비해 열풍건조는 가열에 의한 갈변 현상이 일어난 것이라고 하였으며, 본 연구의 열풍건조 참 외가 $\mathrm{L}$ 값이 가장 낮고 $\mathrm{b}$ 값이 가장 높게 나타난 원인과 유사 하다 생각되며 고온에 장시간 노출되면서 열에 의해 갈변이 된 것이라 사료된다. 건조방법을 달리한 참외의 저장기간 중 색도 $\mathrm{L}$ 값 변화는 저장기간이 길어질수록 모든 처리군이 유의적으로 감소하였다( $\mathrm{p}<0.001)$. 색도 $\mathrm{a}$ 값, $\mathrm{b}$ 값의 변화는
냉풍건조에서 저장기간이 길어질수록 유의적인 값은 나타 나지 않았고 저장기간 동안 안정적으로 유지하는 경향을 나타냈다.

\section{물성 변화}

건조 참외의 저장기간 중 물성 변화에 대한 결과는 Table 5 와 같다. 건조방법 별 저장기간 중 물성 변화는 냉풍건조의 경우 저장 초기부터 저장 15 일차 까지 다른 처리군에 비해 수분함량이 더 높았으며, 물성에서 얻어지는 강도 (songness), 경도(hrdness), 씹음성(cewiness), 깨짐성 (bittleness)의 값이 다른 처리 군에 비해 더 낮게 나타난 것으로 보아 수분과 물성의 연관성을 확인할 수 있었다. 이는 본 연구 냉풍건조 참외의 물성이 낮게 나타난 것의 원인으로 판단된다. 동결건조의 경우 강도(srongness), 경도 (hrdness), 씹음성(cwiness), 깨짐성(bittleness)의 값이 저장 기간이 길어질수록 저장 1 일차 이후 감소하여 안정적으로 유지하는 상태를 나타냈다 $(\mathrm{p}<0.001)$. 탄력성(easticity)에서 는 유의적인 차이를 나타내지 않았으며 저장기간 동안 안정 적으로 유지되는 경향을 나타냈다.

관능평가의 씹음성 기호도 값은 냉풍건조, 열풍건조, 동 결건조 순으로 높게 나타났는데 물성에서 얻어지는 씹음성 의 값이 낮을수록 높은 기호도의 값을 나타냈다. 동결건조 의 경우 참외의 품질이 다른 처리군에 비해 유지되는 편이 나 씹음성 기호도는 냉풍건조가 높은 편으로 냉풍건조의 품질 유지를 위한 추가적인 연구가 필요하다고 생각된다.

Table 4. Changes in Hunter's color value of oriental melon according to drying method

\begin{tabular}{|c|c|c|c|c|c|c|c|}
\hline \multirow{2}{*}{ Parameter } & & \multirow{2}{*}{ Sample } & \multicolumn{4}{|c|}{ Storage period (day) } & \multirow{2}{*}{ F-value } \\
\hline & & & 1 & 5 & 10 & 15 & \\
\hline & \multirow{3}{*}{$\mathrm{L}$} & $\mathrm{HAD}^{1)}$ & 4)c $48.83 \pm 0.19^{\mathrm{BS})}$ & ${ }^{\mathrm{C}} 49.49 \pm 0.036^{\mathrm{B}}$ & ${ }^{b} 53.79 \pm 0.17^{A}$ & ${ }^{c} 42.98 \pm 1.70^{\mathrm{c}}$ & $80.26^{* * *}$ \\
\hline & & $\mathrm{CAD}^{2)}$ & ${ }^{b} 58.56 \pm 0.53^{\mathrm{B}}$ & ${ }^{b} 57.82 \pm 0.42^{B}$ & ${ }^{\mathrm{a}} 64.88 \pm 0.08^{\mathrm{A}}$ & ${ }^{\mathrm{a}} 64.97 \pm 0.94^{\mathrm{A}}$ & $135.12^{* \star *}$ \\
\hline & & $\mathrm{FD}^{3)}$ & ${ }^{\mathrm{a}} 68.54 \pm 0.30^{\mathrm{B}}$ & ${ }^{\mathrm{a}} 74.26 \pm 0.36^{\mathrm{A}}$ & ${ }^{\mathrm{a}} 64.14 \pm 0.62^{\mathrm{C}}$ & ${ }^{\mathrm{b}} 53.55 \pm 076^{\mathrm{D}}$ & $780.96^{* * *}$ \\
\hline & & F-value & $2171.58^{* * \star 7)}$ & $4558.02^{\star * \star}$ & $828.83^{* \star *}$ & $250.28^{* * \star}$ & \\
\hline & \multirow{3}{*}{$\mathrm{a}$} & $\mathrm{HAD}$ & ${ }^{\mathrm{ns}} 0.39 \pm 0.00^{\mathrm{B}}$ & ${ }^{\mathrm{ns}} 0.41 \pm 0.00^{\mathrm{A}}$ & ${ }^{\mathrm{a}} 0.38 \pm 0.00^{\mathrm{C}}$ & ${ }^{\mathrm{a}} 0.41 \pm 0.01^{\mathrm{A}}$ & $92.00^{* * *}$ \\
\hline & & $\mathrm{CAD}$ & ${ }^{\mathrm{ns}} 0.37 \pm 0.00^{\mathrm{NS}}$ & ${ }^{\mathrm{ns}} 0.37 \pm 0.00 \mathrm{NS}$ & ${ }^{\mathrm{b}} 0.36 \pm 0.01^{\mathrm{NS}}$ & ${ }^{\mathrm{b}} 0.36 \pm 0.01^{\mathrm{NS}}$ & NS \\
\hline & & $\mathrm{FD}$ & ${ }^{\mathrm{ns}} 0.34 \pm 0.00^{\mathrm{NS}}$ & ${ }^{\mathrm{ns}} 0.35 \pm 0.00^{\mathrm{NS}}$ & $0.35 \pm 0.00^{\mathrm{NS}}$ & ${ }^{\mathrm{b}} 0.37 \pm 0.00^{\mathrm{NS}}$ & NS \\
\hline & \multirow{4}{*}{$\mathrm{b}$} & F-value & $\mathrm{ns}^{6}$ & ns & $61.00^{* * *}$ & $99.50^{* * *}$ & \\
\hline & & $\mathrm{HAD}$ & ${ }^{\mathrm{ns}} 0.39 \pm 0.00^{\mathrm{B}}$ & ${ }^{\mathrm{ns}} 0.40 \pm 0.00^{\mathrm{A}}$ & ${ }^{\mathrm{a}} 0.38 \pm 0.01^{\mathrm{C}}$ & ${ }^{\mathrm{ns}} 0.40 \pm 0.00^{\mathrm{A}}$ & $24.00^{* * *}$ \\
\hline & & $\mathrm{CAD}$ & ${ }^{\mathrm{ns}} 0.37 \pm 0.00^{\mathrm{NS}}$ & ${ }^{\mathrm{ns}} 0.37 \pm 0.00^{\mathrm{NS}}$ & ${ }^{\mathrm{b}} 0.37 \pm 0.00^{\mathrm{NS}}$ & ${ }^{\mathrm{ns}} 0.37 \pm 0.00^{\mathrm{NS}}$ & NS \\
\hline & & $\mathrm{FD}$ & ${ }^{\mathrm{ns}} 0.35 \pm 0.00^{\mathrm{NS}}$ & ${ }^{\mathrm{ns}} 0.35 \pm 0.00^{\mathrm{NS}}$ & $0.36 \pm 0.00^{\mathrm{NS}}$ & ${ }^{\mathrm{ns}} 0.37 \pm 0.00^{\mathrm{NS}}$ & NS \\
\hline & & F-value & ns & ns & $37.00^{* * *}$ & ns & \\
\hline
\end{tabular}

\footnotetext{
Mean \pm SD.

${ }^{1)} \mathrm{HAD}$ : Hot air-drying

${ }^{2)} \mathrm{CAD}$ : Cold air-drying.

${ }^{3)} \mathrm{FD}$ : Freeze-drying.

${ }^{4) a-d}$ Means with different superscript in the same column are significantly different $(\mathrm{p}<0.05)$ by Duncan's multiple range test

${ }^{5) A-D}$ Means with different superscript in the same row are significantly different $(p<0.05)$ by Duncan's multiple range test.

${ }^{6} \mathrm{~ns}$, none significant.

$7)^{* * *} \mathrm{p}<0.001$
} 
Table 5. Changes in texture $\left(\mathrm{km} / \mathrm{m}^{3}\right)$ of oriental melon according to drying method

\begin{tabular}{|c|c|c|c|c|c|c|c|}
\hline & \multirow{2}{*}{ Parameter } & \multirow{2}{*}{ Sample } & \multicolumn{4}{|c|}{ Storage period (day) } & \multirow{2}{*}{ F-value } \\
\hline & & & 1 & 5 & 10 & 15 & \\
\hline \multirow{24}{*}{$\begin{array}{l}\text { Texture } \\
\left(\mathrm{kg} / \mathrm{cm}^{2}\right)\end{array}$} & \multirow{3}{*}{ Strongness } & $\mathrm{HAD}^{1)}$ & 4)b $0.44 \pm 0.02^{\mathrm{B} 5)}$ & $\left.{ }^{b 5}\right) 0.25 \pm 0.02^{\mathrm{C}}$ & ${ }^{\mathrm{b}} 0.25 \pm 0.01^{\mathrm{C}}$ & ${ }^{\mathrm{a}} 0.50 \pm 0.02^{\mathrm{A}}$ & $208.60^{* * *}$ \\
\hline & & $\mathrm{CAD}^{2)}$ & ${ }^{\mathrm{b}} 0.24 \pm 0.12^{\mathrm{A}}$ & ${ }^{\mathrm{b}} 0.24 \pm 0.02^{\mathrm{A}}$ & $0.18 \pm 0.00^{\mathrm{B}}$ & ${ }^{b} 0.18 \pm 0.04^{\mathrm{B}}$ & $8.91^{* \star}$ \\
\hline & & $\mathrm{FD}^{3)}$ & ${ }^{\mathrm{a}} 3.82 \pm 0.76^{\mathrm{A}}$ & ${ }^{\mathrm{a}} 0.39 \pm 0.02^{\mathrm{B}}$ & ${ }^{\mathrm{a}} 0.46 \pm 0.02^{\mathrm{B}}$ & ${ }^{\mathrm{a}} 0.38 \pm 0.12^{\mathrm{B}}$ & $59.64^{* * *}$ \\
\hline & \multicolumn{2}{|c|}{ F-value } & $63.92^{* *+7)}$ & $60.59^{* \star *}$ & $577.60^{* * *}$ & $14.93^{* *}$ & \\
\hline & \multirow{3}{*}{ Hardness } & $\mathrm{HAD}$ & ${ }^{b} 4.51 \pm 0.14^{B}$ & ${ }^{b} 5.01 \pm 0.53^{A}$ & ${ }^{b_{5}} .34 \pm 0.39^{A}$ & ${ }^{b} 3.38 \pm 0.15^{c}$ & $20.42^{* * *}$ \\
\hline & & $\mathrm{CAD}$ & ${ }^{b} 4.17 \pm 0.12^{B}$ & ${ }^{\mathrm{b}} 4.72 \pm 0.41^{\mathrm{A}}$ & ${ }^{b} 4.44 \pm 0.24^{B}$ & ${ }^{\mathrm{c}} 1.76 \pm 0.12^{\mathrm{B}}$ & $87.61^{* * *}$ \\
\hline & & FD & ${ }^{\mathrm{a}} 27.41 \pm 2.96^{\mathrm{A}}$ & ${ }^{\mathrm{a}} 8.01 \pm 0.63^{\mathrm{B}}$ & ${ }^{\mathrm{a}} 8.26 \pm 0.87^{\mathrm{B}}$ & a $5.13 \pm 0.90^{B}$ & $117.50^{* * *}$ \\
\hline & \multicolumn{2}{|c|}{ F-value } & $181.99^{* * *}$ & $33.74^{* *}$ & $14.94^{* *}$ & $30.09^{* *}$ & \\
\hline & \multirow{3}{*}{ Cohesiveness } & $\mathrm{HAD}$ & a $86.21 \pm 3.01^{\mathrm{A}}$ & ab $82.31 \pm 5.87^{\mathrm{A}}$ & ${ }^{\mathrm{ns}} 85.52 \pm 0.73^{\mathrm{A}}$ & ${ }^{b} 73.57 \pm 0.87^{B}$ & $9.04^{*}$ \\
\hline & & $\mathrm{CAD}$ & a $89.20 \pm 2.75^{\mathrm{A}}$ & a $85.05 \pm 2.40^{\mathrm{AB}}$ & ${ }^{\mathrm{ns}} 79.90 \pm 4.81^{\mathrm{B}}$ & ${ }^{\mathrm{a}} 82.23 \pm 1.51^{\mathrm{B}}$ & $4.97^{*}$ \\
\hline & & FD & ${ }^{b} 56.03 \pm 4.94^{\mathrm{c}}$ & ${ }^{b} 72.41 \pm 5.85^{\mathrm{B}}$ & ${ }^{\mathrm{ns}} 38.62 \pm 1.48^{\mathrm{A}}$ & ${ }^{b} 75.55 \pm 2.94^{\mathrm{B}}$ & $23.20^{* * *}$ \\
\hline & \multicolumn{2}{|c|}{ F-value } & $77.84^{* * \star}$ & $5.36^{*}$ & $\left.\mathrm{~ns}^{6}\right)$ & $15.80^{* *}$ & \\
\hline & \multirow{3}{*}{ Elasticity } & HAD & ${ }^{\mathrm{ab}} 104.29 \pm 4.35^{\mathrm{A}}$ & ${ }^{\mathrm{n}} 105.59 \pm 4.89^{\mathrm{A}}$ & ${ }^{\mathrm{ns}} 105.81 \pm 5.04^{\mathrm{A}}$ & ${ }^{\mathrm{ns}} 87.39 \pm 1.56^{\mathrm{B}}$ & $13.57^{* *}$ \\
\hline & & $\mathrm{CAD}$ & ${ }^{\mathrm{a}} 113.65 \pm 0.55^{\mathrm{NS}}$ & ${ }^{\mathrm{ns}} 100.00 \pm 0.00^{\mathrm{NS}}$ & ${ }^{\mathrm{n}} 110.00 \pm 10.00 \mathrm{NS}$ & ${ }^{\mathrm{ns}} 101.15 \pm 11.51^{\mathrm{NS}}$ & NS \\
\hline & & FD & ${ }^{\mathrm{b}} 88.24 \pm 13.65^{\mathrm{NS}}$ & ${ }^{\mathrm{ns}} 88.25 \pm 13.65^{\mathrm{NS}}$ & ${ }^{\mathrm{ns}} 97.783 .85^{\mathrm{NS}}$ & ${ }^{\mathrm{ns}} 89.83 \pm 2.13^{\mathrm{NS}}$ & NS \\
\hline & \multicolumn{2}{|c|}{ F-value } & $7.23^{*}$ & $\mathrm{~ns}$ & $\mathrm{~ns}$ & ns & \\
\hline & \multirow{3}{*}{ Chewiness } & $\mathrm{HAD}$ & ${ }^{\mathrm{b}} 26.72 \pm 0.95^{\mathrm{A}}$ & ${ }^{b} 14.51 \pm 0.80^{B}$ & ${ }^{\mathrm{b}} 15.11 \pm 0.49^{\mathrm{B}}$ & ${ }^{2} 25.99 \pm 0.10^{A}$ & $193.25^{* *}$ \\
\hline & & $\mathrm{CAD}$ & ${ }^{\mathrm{b}} 15.45 \pm 0.9 \mathrm{1}^{\mathrm{A}}$ & ${ }^{b} 14.47 \pm 1.67^{\mathrm{A}}$ & ${ }^{\mathrm{c}} 10.39 \pm 0.63^{\mathrm{B}}$ & ${ }^{b} 10.39 \pm 1.89^{\mathrm{B}}$ & $11.31^{* *}$ \\
\hline & & FD & ${ }^{\mathrm{a}} 149.73 \pm 15.92^{\mathrm{A}}$ & ${ }^{a} 20.26 \pm 1.39^{B}$ & ${ }^{\mathrm{a}} 27.31 \pm 0.60^{\mathrm{B}}$ & ${ }^{\mathrm{a}} 20.34 \pm 6.35^{\mathrm{B}}$ & $164.10^{* * *}$ \\
\hline & \multicolumn{2}{|c|}{ F-value } & $195.68^{* * \star}$ & $18.51^{* *}$ & $693.26^{* * *}$ & $12.51^{* *}$ & \\
\hline & \multirow{3}{*}{ Brittleness } & $\mathrm{HAD}$ & ${ }^{\mathrm{b}} 27.85 \pm 1.11^{\mathrm{A}}$ & ${ }^{\mathrm{ns}} 15.31 \pm 0.85^{\mathrm{C}}$ & ${ }^{\mathrm{b}} 15.99 \pm 0.85^{\mathrm{c}}$ & ${ }^{\mathrm{a}} 22.71 \pm 0.98^{\mathrm{B}}$ & $116.94^{* *}$ \\
\hline & & $\mathrm{CAD}$ & ${ }^{\mathrm{c}} 17.56 \pm 0.96^{\mathrm{A}}$ & ${ }^{\mathrm{ns}} 14.47 \pm 1.67^{\mathrm{B}}$ & ${ }^{\mathrm{c}} 11.17 \pm 1.73^{\mathrm{c}}$ & ${ }^{b} 10.97 \pm 0.84^{c}$ & $16.93^{* *}$ \\
\hline & & FD & ${ }^{\mathrm{a}} 130.70 \pm 6.30^{\mathrm{A}}$ & ${ }^{\mathrm{ns}} 19.18 \pm 3.61^{\mathrm{B}}$ & $26.71 \pm 1.56^{\mathrm{B}}$ & ${ }^{\mathrm{a}} 18.27 \pm 5.73^{\mathrm{B}}$ & $409.60^{* * *}$ \\
\hline & \multicolumn{2}{|c|}{ F-value } & $842.30^{* * *}$ & ns & $89.72^{* * *}$ & $10.21^{*}$ & \\
\hline
\end{tabular}

Mean \pm SD.

${ }^{1)} \mathrm{HAD}$ : Hot air-drying.

${ }^{2)} \mathrm{CAD}$ : Cold air-drying.

${ }^{3)} \mathrm{FD}$ : Freeze-drying.

${ }^{4) a-d}$ Means with different superscript in the same column are significantly different $(p<0.05)$ by Duncan's multiple range test.

5)A-D Means with different superscript in the same row are significantly different $(p<0.05)$ by Duncan's multiple range test.

${ }^{6} \mathrm{~ns}$ : none significant.

${ }^{7)^{*}} \mathrm{p}<0.05,{ }^{* *} \mathrm{p}<0.01,{ }^{* * *} \mathrm{p}<0.001$.

\section{총 균수 변화}

건조방법을 달리한 건조 참외의 저장기간 중 총 균수 변화에 대한 결과는 Table 6과 같다. 저장기간 별 건조방법 에 따른 총 균수는 저장 1 일차에서 냉풍건조, 열풍건조, 동결건조 순으로 냉풍건조가 가장 높게 나타났다. Bae 등 (27)의 연구에서 일반농산물의 총 균수는 평균 3.74-8.04 $\log \mathrm{CFU} / \mathrm{g}$ 의 수준으로 높게 나타났다. 이는 본 연구의 결과 와 비교해 보았을 때 저장 초기의 총 균수는 낮은 편이었다. 저장기간이 길어질수록 모든 처리군의 균수가 증가하였으 며 균수 변화는 냉풍건조, 열풍건조, 동결건조 순으로 크게 변화하였다. 냉풍건조의 경우 저장 5일차 부터 총 균수가 급격히 증가하여 TNTC(too numerous to count)로 나타났다.
Doly와 Erickson(28)의 건조식품 연구에 따르면 비위생적 인 건조과정과 부적절한 온도관리 및 장기간의 보관으로 곰팡이, 세균 등의 미생물이 오염되고, 증식될 가능성이 높다고 하였다. 이는 열풍건조와 동결건조의 건조 환경에 비해 냉풍건조는 비위생적인 건조과정으로 인해 미생물의 증식이 일어난 것으로 생각된다. 이러한 문제로 저장기간 중의 오염도를 낮추기 위해 저장 시 멸균된 포장지 사용, 미생물 증식이 적은 냉장, 냉동보관이 반드시 필요하다고 생각된다. 또한, 미생물 변화가 가장 적은 동결건조 방법을 활용한 참외 가공 식품이 개발된다면 유통과정과 보관성에 서 상당히 편리함이 부여될 것으로 생각된다. 
Table 6. Changes in the total aerobes (log CFU/g) of oriental melon according to drying method

\begin{tabular}{|c|c|c|c|c|c|}
\hline \multirow{2}{*}{ Sample } & \multicolumn{4}{|c|}{ Storage period (day) } & \multirow{2}{*}{ F-value } \\
\hline & 1 & 5 & 10 & 15 & \\
\hline $\mathrm{HAD}^{1)}$ & ${ }^{\mathrm{a}} 4.89 \pm 0.01^{\mathrm{B}}$ & ${ }^{b} 4.90 \pm 0.04^{\mathrm{B}}$ & ${ }^{b} 4.90 \pm 0.5^{B}$ & ${ }^{\mathrm{a}} 5.34 \pm 0.03^{\mathrm{A}}$ & $110.08^{* * *}$ \\
\hline$C A D^{2)}$ & ${ }^{\mathrm{c}} 5.26 \pm 0.01^{\mathrm{A}}$ & ${ }^{\mathrm{c}} \mathrm{TNTC}^{\mathrm{B}}$ & ${ }^{\mathrm{c}} \mathrm{TNTC}^{\mathrm{B}}$ & ${ }^{\mathrm{c}} \mathrm{TNTC}^{\mathrm{B}}$ & $624100.00^{* * *}$ \\
\hline $\mathrm{FD}^{3)}$ & ${ }^{\mathrm{b}} 5.02 \pm 0.06^{\mathrm{B}}$ & ${ }^{\mathrm{a}} 5.17 \pm 0.05^{\mathrm{A}}$ & ${ }^{\mathrm{a}} 5.14 \pm 0.06^{\mathrm{A}}$ & ${ }^{b} 5.15 \pm 0.03^{A}$ & $5.17^{\star}$ \\
\hline F-value & $98.83^{* * *}$ & $17576.15^{* * *}$ & $12355.02^{* * *}$ & $42704.35^{* * *}$ & \\
\hline
\end{tabular}

Mean \pm SD

${ }^{1)} \mathrm{HAD}$ : Hot air-drying.

${ }^{2)} \mathrm{CAD}$ : Cold air-drying.

${ }^{3} \mathrm{FD}$ : Freeze-drying.

4)a-d Means with different superscript in the same column are significantly different $(\mathrm{p}<0.05)$ by Duncan's multiple range test.

${ }^{5 A-D}$ Means with different superscript in the same row are significantly different $(\mathrm{p}<0.05)$ by Duncan's multiple range test.

6) $\mathrm{p}<0.05,{ }^{* * *} \mathrm{p}<0.001$

\section{관능 평가}

건조방법을 달리한 건조 참외의 관능 특성의 기호도와 강도 결과는 Table 7과 같다.

건조 참외의 외관의 기호도에서는 동결건조가 가장 높게 평가되었다. 색의 기호도와 강도는 동결건조가 가장 높게 평가되었으며 앞서 연구한 참외의 색도 측정에서도 동일한 결과를 보였다. 색은 $\mathrm{L}$ (명도) 값이 높고 $\mathrm{a}$ (적색도), $\mathrm{b}$ (황색 도) 값이 낮을수록 선호도가 높은 것으로 확인되었다. 향의 기호도와 강도는 냉풍건조가 가장 높게 평가되었으며 참외 의 향이 진할수록 선호도가 높은 것으로 나타났다. 이취의 기호도는 냉풍건조의 경우 가장 긍정적으로 평가되었고 강도는 동결건조가 가장 낮게 평가된 것으로 보아 이취는 관능평가 요원들이 인지하지 못하는 정도의 차이 때문인
것으로 판단된다. 맛과 단맛, 쓴맛의 기도호와 강도는 열풍 건조가 가장 높게 평가되었으며, 참외의 맛이 강할수록 선 호도가 높은 것으로 나타났다. 질감과 탄력성의 기호도와 강도는 열풍건조가 가장 높게 평가되었다. 이는 앞서 연구 한 수분과 물성 측정을 비교해 보았을 때 $6 \%$ 정도의 수분을 함유한 건조참외의 질감을 선호하는 것으로 나타났다. 씹 음성의 기호도와 강도는 냉풍건조가 가장 높게 평가되었 다.

전반적인 기호도는 냉풍건조가 가장 높게 평가받았다. 냉풍건조의 경우 향과 씹음성에서 다른 처리군에 비해 높게 평가를 받았다. Lee 등(29)의 건조 무말랭이의 관능검사에 서도 냉풍건조가 냄새, 조직감, 종합적 기호도에서 가장 높은 점수를 받았고 열풍건조는 더 낮은 점수를 나타내었다

Table 7. Sensary evaluation of oriental melon according to drying method

\begin{tabular}{|c|c|c|c|c|c|c|c|c|}
\hline \multirow{2}{*}{ Sample } & \multicolumn{4}{|c|}{ preference } & \multicolumn{4}{|c|}{ The degree of taste } \\
\hline & $\mathrm{HAD}^{1)}$ & $\mathrm{CAD}^{2)}$ & $\mathrm{FD}^{3)}$ & F-value & HAD & CAD & FD & F-value \\
\hline Appearance & $4.55 \pm 1.50$ & $5.05 \pm 1.50$ & $5.20 \pm 1.60$ & & & & & \\
\hline Color & $4.90 \pm 1.29$ & $4.90 \pm 1.68$ & $5.05 \pm 1.31$ & & $5.40 \pm 1.35^{\mathrm{a}}$ & $5.35 \pm 1.04^{\mathrm{a}}$ & $4.00 \pm 1.41^{b}$ & $7.70^{* * *}$ \\
\hline Flavor & $4.95 \pm 1.70^{\mathrm{ab} 4)}$ & $5.65 \pm 1.50^{\mathrm{a}}$ & $4.35 \pm 1.14^{\mathrm{b}}$ & $3.95^{* 5)}$ & $5.00 \pm 1.41$ & $5.60 \pm 1.14$ & $4.70 \pm 1.53$ & \\
\hline Off-Flavor & $4.50 \pm 1.50$ & $5.25 \pm 1.59$ & $4.10 \pm 1.80$ & & $4.50 \pm 1.79$ & $4.45 \pm 1.73$ & $4.20 \pm 1.77$ & \\
\hline Taste & $5.40 \pm 1.39$ & $5.25 \pm 1.68$ & $4.90 \pm 1.52$ & & $5.35 \pm 1.50$ & $5.20 \pm 1.64$ & $4.35 \pm 1.76$ & \\
\hline Sweetness & $5.65 \pm 1.39$ & $5.40 \pm 1.35$ & $5.00 \pm 1.59$ & & $5.65 \pm 1.39$ & $5.20 \pm 1.32$ & $5.40 \pm 1.31$ & \\
\hline Bitterness & $3.95 \pm 1.93$ & $3.55 \pm 1.76$ & $3.65 \pm 1.79$ & & $3.05 \pm 2.01$ & $3.05 \pm 1.67$ & $2.70 \pm 1.63$ & \\
\hline Texture & $5.45 \pm 1.10$ & $5.40 \pm 1.54$ & $4.80 \pm 1.51$ & & $5.45 \pm 1.39$ & $4.65 \pm 1.87$ & $4.75 \pm 1.65$ & \\
\hline Springness & $5.00 \pm 1.26$ & $4.85 \pm 1.76$ & $4.85 \pm 1.53$ & & $5.10 \pm 1.77$ & $4.95 \pm 1.79$ & $4.70 \pm 1.63$ & \\
\hline Chewsiness & $5.35 \pm 1.46$ & $5.45 \pm 1.73$ & $5.00 \pm 1.38$ & & $5.20 \pm 1.51$ & $4.70 \pm 1.81$ & $4.65 \pm 1.76$ & \\
\hline Overall preference & $5.20 \pm 1.67$ & $5.45 \pm 1.70$ & $4.65 \pm 1.66$ & & & & & \\
\hline $\begin{array}{l}\text { Mean } \pm \text { SD. } \\
H A D \text { : Hot air-drying. } \\
\text { CAD : Cold air-drying } \\
\text { FD : Freeze-drying. } \\
\text { ADD Means with different } \\
{ }^{A}<0.05\end{array}$ & & & & 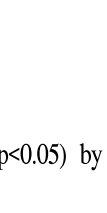 & & & & \\
\hline
\end{tabular}


고 하였다. 이는 본 연구와 유사한 결과를 나타내었으며 건조 제품 개발 시 향과 씹음성이 기호성에 상당한 영향을 미칠 것으로 생각된다.

\section{요 약}

본 연구는 참외의 건조 방법을 달리하여 저장기간에 따 른 품질특성 변화와 관능적특성을 연구하고, 참외의 섭취 와 보관이 편리한 간편식 형태의 가공식품개발을 위한 기초 자료로 이용하고자 하였다. 건조 참외의 수분함량은 냉풍 건조에서 5일차부터 안정적으로 유지하는 경향을 보였다. $\mathrm{pH}$ 변화는 저장기간에 따라 약 $\mathrm{pH}$ 5-6 정도로 유의적인 차이를 나타냈으며 $(\mathrm{p}<0.01,0.001)$, 당도 변화에서는 모든 처리군에서 유의적으로 증가하였다. 색도에서는 $\mathrm{L}$ 값은 동 결건조에서 가장 높게 나타났다. $\mathrm{a}$ 값은 냉풍건조, 동결건조 에서 유의적인 변화는 없었고 저장기간 동안 유지하는 경향 을 나타냈다. 물성 변화는 동결건조의 경우 강도, 경도, 씹음 성, 깨짐성의 값이 저장기간이 길어질수록 저장 5 일차부터 유지하는 경향을 나타냈다 $(\mathrm{p}<0.001)$. 탄력성에서는 유의적 인 차이를 나타내지 않았으며 저장기간 동안 유지되는 경향 을 나타냈다. 총 균수 변화는 동결건조에서 저장 1 일차에 $4.02 \log \mathrm{CFU} / \mathrm{g}$ 으로 가장 낮았고, 저장기간이 길어질수록 증가하였으나 다른 처리군에 비해 변화가 적었다. 관능적 특성으로 전반적인 기호도에서는 냉풍건조가 가장 높게 평가되었으며, 냉풍건조 관능적 특성 평가 결과 향과 씹음 성에서 높게 나타났다. 건조 참외의 품질특성 변화를 방지 하기 위해 위생저인 건조 환경, $4^{\circ} \mathrm{C}$ 저온 저장, 진공 포장 및 멸균된 포장지 이용 등의 저장 방법의 추가적인 연구가 필요하다고 생각한다. 또한 저장기간 중 품질 변화가 가장 적고 기호도가 가장 높은 냉풍건조를 이용한 참외 가공식품 및 건강식품의 개발에 기초자료가 될 것으로 생각된다.

\section{References}

1. Kim OM, Park SI, Jo YJ, Jeong YJ (2014) Quality characteristics of oriental melon Makgeolli using uncooked rice by oriental melon concentrate. Korean J Food Preserv, 21, 536-543

2. Kim JG, Jeong ST, Jang HS, Kim YB (1997) Quality properties of dried melon with different prtreatments. Korean J Food Preserv, 4, 147-153

3. Kim TY, Kim SB, Jeong YJ, Shin JS, Park NY (2013) Quality properties of Takju mash vinegar added muskmelon. Korean J Food preserv, 10, 522-526

4. Nam JH, Ahn JJ, Suh JK, Kim DW (2013) Quality characteristics of a kimchi containing oriental melon peel. Korean J Food Preserv, 20, 518-523

5. Lee GD, Kwon SH, Lee MH, Kim SK, Ju GJ, Kwon JH (2004) Change of organoleptic properties with heating concentration of oriental melon juice. Korean J Food Preserv, 11, 130-133

6. Park JD, Hong SI, Park HW, Kim DM (2000) Extending shelf-life of oriental melon (Cucumis melon L.) by modified atmosphere packaging. Korean J Food SCI Technol, 32, 481-490

7. Cha SK, Chun HI, Hong SS, Kim WJ, Koo YJ (1993) Manufacture of fermented cantaloupe melon with lactic starter culture. Korean J Food Sci Technol, 25, 386-390

8. Hwang HY, Hwang IW, Chung SK (2015) Quality characteristics and volatile flavor compounds of oriental melon wine using freeze concentration. J Korean Soc Food Sci Nutr, 44, 1347-1355

9. Lee GD, Kim KS, Lee MH (2005) Optimization of preparation condition on oriental melon jam by response surface methodology. Korean J Food Preserv, 12, 216-222

10. Son IN (2017) Study on the consumer perception and factors of purchasing decision on focused on university students in Cungcheong areaconvenience food. Korean Hospitality and Tourism Academe, 26, 101-112

11. Lee HS (2017) Antiocidant of extracts from paprika and characteristics of the dried paprika by drying methods. MS Thesis, Daegu Haany University, Korea, p 46-49

12. Lee S, Kim JK (2015) Quality chatacteristics of Aronia melanocarpa by different drying method. Korean J Food Preserv, 22, 56-62

13. Hong JH, Lee WY (2004) Quality characteristics of osmotic dehydrated sweet pumpkin by different drying methods. Korean J Soc Food Sci, 33, 1573-1579

14. Ministry of Agriculture, Food and Rural Affairs (2016) Situation of segment market in processed food (dried fruit and vegetables). Naju, Korea, p 1-100.

15. Jeong JW, Seong JM, Park KJ, Lim JH (2007) Quality characteristics of semi-dried red pepper (Capsicum Annuum L.) using hot-air drying. Korean J Food Preserv, 14, 591-597

16. Kim GH, Kang JK, Park HW (2000) Quality maintenance of minimally processed chinese cabbage for Kimchi preparation. Korean J Soc Food Sci, 29, 218-223

17. Holdsworth SD (1971) Dehydration of food products. J Food Technol, 6, 331-370

18. Christopher GJ (1997) Industrial drying of food. Blackie 
Academic \& Professional, NY, USA, p 1-6

19. Litvin S, Mannheim CH, Miltz J (1998) Dehydration of carrots by a combination of freeze drying, microwave heating and air or vaccum drying. J Food Eng, 36, 103-111

20. Ko YT, Kang JH, Kim TE (2001) Quality of freeze-dried kimchi. Korean J Food Sci Technol, 33, 100-106

21. Ko YT, Kang JH (2003) Quality of freeze-dried Yulmoo-kimchi. Korean J Food Sci Technol, 35, 254-259

22. Yoo YS (2018) Changes in microbial growth of dried foods by storage temperature and relative humidity. MS Thesis, Yeungnam University, Korea, p 16-17

23. Kim YJ, Lee SJ, Kim MY, Kim GR, Chung HS, Park HJ, Kim MO, Kwon JH (2009) Physicochemical and organoleptic qualities of sliced-dried persimmons as affected by methods. Korean J Food Sci. Technol, 41, 64-68

24. Lee S, Moon HK, Lee SW, Moon JN, Kim JK (2014) Effects of drying methods on quality characteristics and antioxidative effects of Omija (Schizandra chinesis bailon). Korean J Food Preserv, 21, 341-349
25. Kwon JH, Lee GD, Lee SJ, Chung SK, Choi JU (1998) Changes in chemical components and physical properties with freeze drying and hot air-drying of Dioscorea batatas. J Korean Soc Food Sci Nutr, 27, 908-913

26. Park SJ, Choi YB, Ko JR, Rha YA, Lee HY (2014) Effects of drying methods on the quality and physiological activities of Blueberry (Vaccinium ashe1). Korean J Culinary Res, 20, 55-64

27. Bae YM, Hong YJ, Kang DH, Heu SG, Lee SY (2011) Microbial and pathogenic contamination of ready-to-eat fresh vegetables in Korea. Korean J Food Sci Technol, 43, 161-168

28. Doyle, M, P, Erickson, M, C (2008) Summer meeting 2007 - the problems with fresh produce: an overview. Journal of applied microbiology, 105, 317-330

29. Lee WY, Cha WS, Oh SL, Cho YJ, Lee HY, Lee BS, Park JS, Park JH (2006) Quality characteristics of dried radish (Raphanus sativus) by drying methods. Korean J Food Preserv, 13, 37-42 